sites in the myocardium. A delay of two to three hours between peak plasma level and maximal effect seems likely. The fall from peak plasma levels is due to this process in addition to the effects of "excretion and metabolization."

The attribution to toxicity of the nausea noted soon after an oral dose of $0.5 \mathrm{mg}$ of "new" Lanoxin is unfortunate, as the associated plasma levels were relatively low and any adverse effect on the myocardium seems unlikely.

When considering the dose of "new" Lanoxin it must be borne in mind that traditional regimens were based on tablets of similar properties which were in general use up to 1970. Comparison of the plasma levels obtained with the same radioimmunoassay technique in $1970^{1}$ and $1972^{2}$ confirms that the less well-absorbed preparation described as "old" Lanoxin was in use between 1970 and 1972 only.

Patients differ considerably in their response to variations in the biological availability of digoxin. Although some subjects show little difference in plasma levels when changed from the "old" to the "new" preparation, those who absorb digoxin relatively poorly will show a very great increase. No general rules of dose equivalence for the two preparations can be given; each patient must be assessed individually. -We are, etc.,

\section{St. Bartholomew's Hospital,}

JOHN HAMER Royal Sussex County Hospital,

Douglas Chamberlain Brighton 1 Chamberlain, D. A., White, R. J., Howard, M. R. R, $1970,3,429$.

2 Shaw, T. R. D., Howard,

\section{Grades of Hypothyroidism}

SIR,-We were interested in the article on grades of hypothyroidism by Dr. D. C. Evered and others (17 March, p. 657). Since we first described preclinical hypothyroidism in $1967^{1}$ on the basis of thyroid antibodies and the hypercholesterolaemia that may occur in this condition, accurate thyroid stimulating hormone (T.S.H.) measurements have clearly defined the stages of thyroid failure in autoimmune thyroiditis. Our classification ${ }^{2}$ of the stages of thyroid failure, which we made in 1970 , is only semantically different from that proposed by Dr. Evered and his colleagues. Our experience suggests that after many years in the stage of preclinical hypothyroidism progression to hypothyroidism occurs rather rapidly over six months to a year. Twenty-two of our first 50 patients progressed in this way to hyperihyroidism in a comparatively short time.

Dr. Evered and his colleagues used $10 \mathrm{IU}$ of TSH for assessing the thyroid reserve. We found this test superstimulatory and occasionally not without danger in patients with ischaemic heart disease. We measured the thyroid reserve using $2.5 \mathrm{IU}$ doses of TSH by the method described by Hobbs et $a .^{3}$ Tests for thyroid reserve were compared with TSH estimations kindly done by Professor R. Hall and his colleagues. Patients with preclinical hypothyroidism and raised TSH levels all had reduced thyroid reserves. In patients with suspected preclinical hypo- thyroidism and normal TSH levels the thyroid reserve was sometimes reduced (unpublished). This suggests either that measurement of the thyroid reserve is more sensitive than the TSH level or it is less discriminatory.

Now that it is at last being accepted that preclinical hypothyroidism does exist it is mportant to know how to find these cases. Dr. Evered and his colleagues, with the advantage of being able to do large batches of TSH estimations, have made a study of only 22 patients. Ten of the 22 were extracted from their "normal" controls accidentally found to have raised serum TSH concentrations. The next largest group were six patients who were found by "observation of a small goitre in relatives or friends visiting outpatients." We collected 50 patients with preclinical hypothyroidism in about a year, though they had been followed up for longer periods. Twenty-nine were patients with a past history of thyrotoxicosis or goitre but 10 presented with coronary artery disease.

One should always exclude preclinical hypothyroidism in a young woman with coronary artery disease, especially if the serum cholesterol is raised and there is no corneal arcus and also if there is a family history of specific autoimmune disease or coronary artery disease. Since our original 50 patients with preclinical hypothyroidism we have found many more each year. The serum cholesterol levels always fall with clofibrate, but probably thyroxine will be more effective than clofibrate in preventing the progression of the degenerative arterial disease.

Lastly, we agree with Dr. Evered and his colleagues that cytoplasmic antibodies are more important than antibodies to thyroglobulin. The Helsinki ${ }^{4}$ survey which failed to find autoimmune thyroiditis a significant factor in the aetiology of coronary artery disease did not use the immunofluorescent techniques for their thyroid antibody studies. -We are, etc.,

\section{P. B. S. FOWLER}

J. SWALE

H. ANDREWS

H. IKRAM

Charing Cross Hospital,

S. O. BANIM

1 Fowler, P. B. S., and Swale, J., Lancet, 1967, Fowler, P. B. S., and Swale, J., Lancet, 1967,
Fowler, P. B. S., Swale, J., and Andrews, H., Lancet, i970, 2, 488

3 Hobbs, J. R., Bayliss, R. I. S., Maclagan, N. F., Lancet, 1963, 1, 8.

Heinonen, O. P., Gordin, A., Aho, K., Punsar, S.,
Puro, K., Lancet, 1972, 1, 785.

\section{Postoperative Empyema and Survival in Lung Cancer}

SIR,-Your leading article (3 March, p. 504) raised many points of interest. Contrary to your belief Le Roux ${ }^{1}$ did not find an improved survival rate after empyema, nor have more recent, larger studies. ${ }^{2}$ Nevertheless, the clinical impression is still held, as you state, that people surviving empyemas after lung resection for carcinoma do have an increased chance of surviving five years. You refer to Coley's work ${ }^{3}$ as indicating that infection may have a beneficial effect in helping eradicate cancer. I would like to suggest that it is the pyrexia that accompanies infection which is the important factor.
Westermark in $1898^{4}$ was perhaps the first person to use heat alone in tumour therapy, but more recently extensive investigation into the use of hyperthermia in the treatment of solid tumours has been undertaken. Selawry ${ }^{5}$ showed that in tissue culture the growth of cells derived from human tumours could be inhibited by a temperature of 39 $40^{\circ} \mathrm{C}$. This is arguably an ideal treatment as it has a selective effect on malignant cells, and normal cells are unaffected. Muckle and Dickson $^{6}$ have admirably demonstrated in an animal model how effective a treatment hyperthermia can be. It has been used in man with demonstrable results both by regional perfusion of prewarmed blood ${ }^{7}$ and total body hyperthermia, ${ }^{8}$ and further clinical trials are being carried out.

It may be that surgery will remain the main treatment for malignant disease, but it is becoming apparent that further improvement in results will occur only when we learn to utilize other factors acting to eliminate malignant disease. These adjuvant forms of treatment may include chemotherapy, immunotherapy, and perhaps hyperthermia. The clinical beginning of hyperthermia at the end of the nineteenth century may yet bear fruition before the end of the twentieth.-I am, etc.,

G. BONE

Department of Surgery

University of Newcastle upon Tyne

1 Le Roux, B. T., British fournal of Surgery, 1965 52,89 .

2 Lawton, R. L., and Keehn, R. J., fournal of Surgical Oncology, 1972, 4, 466.
Coley, W. B., American Yournal of the Medical Coley, W. B., American Yournal of the Medical
Sciences, 1906, 131, 375 Westermark, F.,

5 Selawry, O. S., Goldstein, M. N.. and McCormick, T., Cancer Research, 1957, 17, 785 . British fournal of Cancer, 1971, 25, 771.

8 Cavaliere, R., et al., Cancer, 1967, 20, 1351. $1971,1,1275$.

\section{Suicidal Attempt with Practolol}

SIR,-Tolerance to beta-adrenergic blocking agents varies considerably. There is also a definite difference in the cardiodepressive action of different beta-adrenergic drugs. We therefore think it of interest to report an attempted suicide with practolol in a patient with severe heart disease.

The patient, a man aged 39 , had rheumatic mitral disease. In 1964 mitral commissurotomy was performed and in 1969 the mitral valve was replaced with an artificial ball-valve. Thereafter the patient's main problems were recurrent attacks of atrial fibrillation and flutter. He also had several periods of depression and was treated three times in a mental hospital. During the last year he had been taking digoxin (0.375 $\mathrm{mg} /$ day) and warfarin. For prevention of dysrhythmias he had been taking $200 \mathrm{mg}$ of practolol twice a day.

During a depressive mood he took 90 tablets $(9,000 \mathrm{mg})$ of practolol. Three hours later he was taken to hospital. On admission his general condition was good. The heart rate was 70 beats $/ \mathrm{min}$ and the blood pressure $90 / 70 \mathrm{~mm}$ Hg. There were no signs of cardiac decompensation. During the next hour the heart rate dropped to $64 / \mathrm{min}$, but within two hours it regained the previous value. The blood pressure rose simultaneously to $100 / 70$ and later to $110 / 75 \mathrm{~mm} \mathrm{Hg}$, which was his usual level. The further course was uneventful and no special treatment was necessary at any time. Blood samples taken $4 \frac{1}{2}$ and $9 \frac{1}{2}$ hours after ingestion of practolol gave serum concentrations of $40 \mu \mathrm{g} / \mathrm{ml}$, and $58.6 \mu \mathrm{g} / \mathrm{ml}$ respectively (I.C.I. 